40 Years of Continuous Renal Replacement Therapy 


\title{
Contributions to Nephrology
}

\author{
Vol. 194
}

Series Editor

Claudio Ronco vicenza 


\section{Years of \\ Continuous Renal \\ Replacement Therapy}

Volume Editors

Rinaldo Bellomo Melbourne, VI

John A. Kellum Pittsburgh, PA

Gaetano La Manna Bologna

Claudio Ronco vicenza

27 figures, 20 in color, and 15 tables, 2018

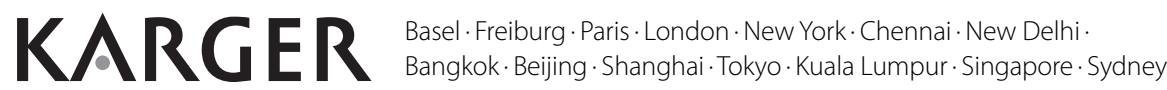




\section{Contributions to Nephrology}

(Founded 1975 by Geoffrey M. Berlyne)

\section{Rinaldo Bellomo \\ School of Public Health and Preventive \\ Medicine \\ Monash University \\ 99 Commercial Road \\ 3004 Melbourne, VI (Australia)}

\section{Gaetano La Manna}

Nephrology, Dialysis and Renal

Transplant Unit

St. Orsola Hospital

University of Bologny

Via Massarenti 9

IT-40138 Bologna (Italy)

\author{
John A. Kellum \\ Center for Critical Care Nephrology \\ 604 Scaife Hall \\ 3550 Terrace Street \\ Pittsburgh, 15261 PA (USA)
}

\section{Claudio Ronco}

Department of Nephrology

Dialysis and Transplantation

International Renal Research Institute

(IRRIV)

San Bortolo Hospital

Viale Rodolfi, 37

IT-36100 Vicenza (Italy)

Library of Congress Cataloging-in-Publication Data

Names: Bellomo, R. (Rinaldo), 1956- editor. | Kellum, John A., editor. | La

Manna, Gaetano, editor.| Ronco, C. (Claudio), 1951- editor.

Title: 40 years of continuous renal replacement therapy / volume editors,

Rinaldo Bellomo, John A. Kellum, Gaetano La Manna, Claudio Ronco.

Other titles: Forty years of continuous renal replacement therapy |

Contributions to nephrology ; v. 194. 0302-5144

Description: Basel ; New York : Karger, 2018. | Series: Contributions to

nephrology, ISSN 0302-5144; vol. 194 | Includes bibliographical

references and indexes.

Identifiers: LCCN 2018003204| ISBN 9783318063066 (hard cover : alk. paper) |

ISBN 9783318063073 (electronic version)

Subjects: | MESH: Renal Insufficiency--therapy | Renal Replacement Therapy |

Renal Replacement Therapy--trends

Classification: LCC RC918.R4 | NLM WJ 342 | DDC 616.6/14--dc23 LC record available at https://lccn.loc.gov/2018003204

Bibliographic Indices. This publication is listed in bibliographic services, including Current Contents ${ }^{\circledR}$ and Index Medicus.

Disclaimer. The statements, opinions and data contained in this publication are solely those of the individual authors and contributors and not of the publisher and the editor(s). The appearance of advertisements in the book is not a warranty, endorsement, or approval of the products or services advertised or of their effectiveness, quality or safety. The publisher and the editor(s) disclaim responsibility for any injury to persons or property resulting from any ideas, methods, instructions or products referred to in the content or advertisements.

Drug Dosage. The authors and the publisher have exerted every effort to ensure that drug selection and dosage set forth in this text are in accord with current recommendations and practice at the time of publication. However, in view of ongoing research, changes in government regulations, and the constant flow of information relating to drug therapy and drug reactions, the reader is urged to check the package insert for each drug for any change in indications and dosage and for added warnings and precautions. This is particularly important when the recommended agent is a new and/or infrequently employed drug.

All rights reserved. No part of this publication may be translated into other languages, reproduced or utilized in any form or by any means electronic or mechanical, including photocopying, recording, microcopying, or by any information storage and retrieval system, without permission in writing from the publisher.

(c) Copyright 2018 by S. Karger AG, P.O. Box, CH-4009 Basel (Switzerland)

www.karger.com

Printed on acid-free and non-aging paper (ISO 9706)

ISSN 0302-5144

e-ISSN 1662-2782

ISBN 978-3-318-06306-6

e-ISBN 978-3-318-06307-3 


\section{Contents}

VII Preface

Ronco, C. (Vicenza); Bellomo, R. (Melbourne, VI); Kellum, J.A. (Pittsburgh, PA);

La Manna, G. (Bologna)

1 Evolution of Technology for Continuous Renal Replacement Therapy: Forty Years of Improvement

Ronco, C. (Vicenza)

15 Evolution of Vascular Access and Anticoagulation

Honore, P.M.; Spapen, H.D. (Brussels)

25 Indications and Timing of Continuous Renal Replacement Therapy Application

Bagshaw, S.M. (Edmonton, AB); Wald, R. (Toronto, ON)

38 Prescription and Delivery of the Right Continuous Renal Replacement Therapies Dose

Villa, G. (Florence); Neri, M.; Ronco, C. (Vicenza); Cerdá, J. (Albany, NY)

51 Techniques and Modalities of Continuous Renal Replacement Therapy Ostermann, M. (London)

60 Fluid Management on Continuous Renal Replacement Therapy Murugan, R.; Kellum, J.A. (Pittsburgh, PA)

70 Membranes and Sorbents

Clark, W.R. (West Lafayette, IN); Gao, D. (Seattle, WA); Lorenzin, A.;

Ronco, C. (Vicenza)

80 Advances in Machine Technology

Clark, W.R. (West Lafayette, IN); Villa, G. (Florence); Neri, M.; Ronco, C. (Vicenza)

90 Extra-Renal Indications for Continuous Renal Replacement Therapy Vaara, S.T.; Bellomo, R. (Melbourne, VI)

99 Technical Complications of Continuous Renal Replacement Therapy Ricci, Z. (Rome); Romagnoli, S. (Florence) 
109 Clinical Complications of Continuous Renal Replacement Therapy

Sigwalt, F.; Bouteleux, A.; Dambricourt, F.; Asselborn, T.; Moriceau, F.;

Rimmelé, T. (Lyon)

118 Discontinuation of Continuous Renal Replacement Therapy and Dialysis Dependence

Romero-González, G. (Vicenza/Medellín); Lorenzin, A.; Neri, M.;

Ferrari, F. (Vicenza); Molano-Triviño, A. (Vicenza/Bogotá); Brendolan, A.;

Ronco, C. (Vicenza)

126 Ensuring Quality of Care through Monitoring of Continuous Renal Replacement Therapies

Rosner, M.H. (Charlottesville, VA)

134 Continuous Renal Replacement Therapy Quality Control and Performance Measures

Shen, B.; Xu, J.; Wang, Y.; Jiang, W.; Teng, J.; Ding, X. (Shanghai)

146 Pediatric Continuous Renal Replacement Therapy for " 40 Years of Continuous Renal Replacement Therapy"

Goldstein, S.L. (Cincinnati, OH)

155 From Continuous Renal Replacement Therapies to Multiple Organ Support Therapy

Ricci, Z. (Rome); Romagnoli, S. (Florence); Ronco, C. (Vicenza);

La Manna, G. (Bologna)

170 Author Index

171 Subject Index 


\section{Preface}

Forty years ago, Peter Kramer in Gottingen treated the first patient with continuous arterio-venous hemofiltration. Such techniques represented the real alternative for those patients in which hemo or peritoneal dialysis were precluded or contraindicated. Continuous arterio-venous hemofiltration was the first of several other techniques subsequently called continuous renal replacement therapies (CRRT). In this time frame, we can identify 4 different decades: the first was dedicated to the exploration and development of this new therapeutic approach; the second was characterized by the birth of a new specialty called critical care nephrology; the third decade was the time of new devices and machines specifically designed for CRRT; and the last decade was mainly characterized by the interaction that took place among different specialists who recognized the utility of extracorporeal therapies for multiple organ support and sepsis. Many of the advances in this field are linked to the results of the consensus conferences of the Acute Disease Quality Initiative group. Forty years later, we have new machines and new techniques that are the result of a long history of developments, studies, and practices. It is the right time to make an appraisal of CRRT and its role in the management of the critically ill patient with acute kidney injury as a celebration of an important moment of critical care nephrology. We decided to make this 40 -year anniversary book as a volume of the series "Contributions to Nephrology," since Karger has graciously accepted to publish it with accuracy and care. The content of this book features contributions from prominent CRRT experts from all over the world. This book represents an important tool for educating a new generation of nephrologists and intensivists, while at the same time providing the most advanced CRRT users with the latest technological information, the most updated clinical evidence, and the personal opinion of key leaders who contributed to make the last 40 years of history in the field.

Claudio Ronco, Vicenza

Rinaldo Bellomo, Melbourne, VI

John A. Kellum, Pittsburgh, PA

Gaetano La Manna, Bologna 
